Article

\title{
Flavonoids of Kudzu Root Fermented by Eurtotium cristatum Protected Rat Pheochromocytoma Line 12 (PC12) Cells against $\mathrm{H}_{2} \mathrm{O}_{2}$-Induced Apoptosis
}

\author{
Bo Zhang ${ }^{1,2}$, Wen $\mathrm{Li}^{3}$ (1D) and Mingsheng Dong ${ }^{1, *}$ \\ 1 College of Food Science and Technology, Nanjing Agricultural University, Nanjing 210095, China; \\ vip_zhangbo87@163.com \\ 2 College of Food Science and Technology, Bohai University, Jinzhou 121013, China \\ 3 Jiangsu Key Construction Laboratory of Food Resource Development and Quality Safe, Xuzhou Institute \\ Technology, Xuzhou 221008, China; wenlisony@126.com \\ * Correspondence: dongms@njau.edu.cn; Tel./Fax: +86-25-8439-9090
}

Received: 20 November 2017; Accepted: 15 December 2017; Published: 19 December 2017

\begin{abstract}
Novel bioactive components have greatly attracted attention as they demonstrate health benefits. Reversed-phase high performance liquid chromatography (RP-HPLC) showed that isoflavonoid compounds of kudzu root (Pueraria lobata) fermented by Eurtotium cristatum and extracted using de-ionized water were higher active compared with non-fermented. A model of $\mathrm{H}_{2} \mathrm{O}_{2}$-inducd cell damage was built using rat pheochromocytoma line 12 (PC12) cell to observe the protective effect of non-fermented kudzu root (Pueraria lobata) (NFK) and fermented kudzu root (Pueraria lobata) (FK). Cell viability and apoptosis were analyzed through inverted microscopy and flow cytometry. The level of lactate dehydrogenase, catalase activity, superoxide dismutase, glutathione, and reactive oxygen species (ROS) were evaluated. Results showed that NFK and FK could significantly protect $\mathrm{PC} 12$ cell against damage caused by $\mathrm{H}_{2} \mathrm{O}_{2}$-induced oxidative stress. The intracellular antioxidant system was increased, protected the cell membrane inhibit $\mathrm{H}_{2} \mathrm{O}_{2}$-induced apoptosis by scavenging of ROS. Moreover, NFK and FK regulated the cell cycle to prevent cell apoptosis. Isoflavonoid from the kudzu root especially fermented kudzu root with E. cristatum are potentially therapeutic drugs against diseases induced by oxidative damage.
\end{abstract}

Keywords: kudzu root (Pueraria lobata); PC12 cell; $\mathrm{H}_{2} \mathrm{O}_{2}$-induced damage; reactive oxygen species; apoptosis

\section{Introduction}

Health foods and their by-products have recently attracted considerable attention. Various phytochemical components have been recognized as natural antioxidants, which are used to counteract reactive oxygen species. Among these phytochemical compounds, phenols have demonstrated potent antioxidant activity, as indicated by the reduction of chronic diseases [1]. Consequently, bioactive phenolic acid compounds have received great considerable attention in the food and clinical sectors because of their potential as antioxidants [2]. The beneficial effects of isoflavonoids are attributed to their anti-oxidative and phytoestrogenic properties [3]. Phenolic compounds and their anti-oxidant activity in legume seeds have been reported by several studies [4,5]. Pathogenesis and progression of various human diseases, including cancer, neurodegenerative diseases, and Alzheimer's disease (AD), are caused by two critical factors, namely, free radical and oxidative stress [6,7]. These diseases are possibly associated with overproduction of reactive oxygen species (ROS) or reactive nitrogen species $[8,9]$. 
Fan et al. [10] reported that apoptosis of neuronal cell contributes to the apoptotic pathway, and such contribution is caused by mitochondrial homeostasis, which is affected by major reactive oxygen species (ROS) (e.g., superoxide radical and hydroxyl radical, by energy production, and mediate mitochondrial-dependent pathway). Cells can protect themselves from damages, injury, and apoptosis induced by oxidative stress through their internal antioxidant defense mechanisms [10]. Meanwhile, estrogen therapy is one of the most compelling potential strategies to prevent AD [11]. Dietary flavonoids have received great attention as potential anticancer agents, cardioprotectants, and inhibitors of neuro de-generation because of their antioxidant properties and their ability to modulate signaling pathways $[12,13]$.

Rat pheochromocytoma line 12 (PC12) cell provides a useful model system for neurological and neurochemical studies [14]. In PC12 cell, neuronal apoptosis may be due to different apoptotic pathways: intrinsic or extrinsic for example [15]. $\mathrm{H}_{2} \mathrm{O}_{2}$ is the main component of reactive oxygen species, and it is also an inducer of oxidative stress. Exogenous hydrogen peroxide can induce a variety of cells to cause injury or even apoptosis due to oxidation. In $\mathrm{PC} 12$ cells, $\mathrm{H}_{2} \mathrm{O}_{2}$ peroxide can induce intracellular reactive oxygen species (ROS), thereby motivating cell oxidative damage, resulting in the expression of related genes or related apoptotic proteases, resulting in cell apoptosis. [16]. $\mathrm{H}_{2} \mathrm{O}_{2}$ in PC12 cell is recently demonstrated to induce cytotoxicity, as well as membrane and antioxidant enzyme activities, such as superoxide dismutase (SOD) and catalase (CAT) activities, moreover, $\mathrm{H}_{2} \mathrm{O}_{2}$ increases ROS level and caspase- 3 activity $[17,18]$.

Lin et al. [19] reported that herbal remedies are a type of alternative medicine that employs traditional herbal treatments to heal illnesses and diseases. Although herbal medicines, which are usually acquired from diverse natural resources, are traditional methods employed outside of conventional medicine, many people worldwide still rely on herbal medicines for health care [19].

Food-derived antioxidants, such as phytochemicals, have recently received increasing attention because of their function as chemopreventive agents against oxidative damages. Lu et al. [14] reported that natural flavonoids displaying a lipophilic chemical structure and antioxidant properties are promising candidates for neurodegenerative intervention. Many plants and cereals were proven have against harmful-free radicals due to the presence of antioxidant compounds such as isoflavones and phenolic acids. Moreover, Zhang et al. [20] have found that puerarin protects PC12 cells against $\beta$-amyloid-induced cell injury. Puerarin is one of the major isoflavonoid compound isolated from the root of wild leguminous creepers [21]. Kudzu root (Pueraria lobata) protects neurons from oxidative stress-induced apoptosis. However, the effect of kudzu root (Pueraria lobata) and fungus-fermented kudzu root on apoptosis of PC12 cell during $\mathrm{H}_{2} \mathrm{O}_{2}$-induced damage has not yet been investigated. This study examined whether E. cristatum fermented kudzu root (Pueraria lobata) exert neuro-protective effects against $\mathrm{H}_{2} \mathrm{O}_{2}$-induced ROS production and whether fermented kudzu root inhibits apoptosis of PC12 cell.

\section{Results and Discussion}

\subsection{Special Isoflavonoid Contents of NFK and FK}

Figure 1 and Table 1 showed the NFK and FK samples contain high amount isoflavonoid. Wang et al. [22] reported that puerarin, daidzein, and genistein are the major isoflavonoids in kudzu root (Pueraria lobata) [23]. Table 1 showed that seven isoflavonoid compounds and one phenolic acid, namely puerarin, daidzin, glycitin, genistin, daidzein, glycitein, genistein and shikimic acid have changed during fermentation time as revealed by RP-HPLC. E. cristatum could increase or decrease the isoflavonoid and phenolic acid contents of kudzu root, for instance, daidzein level was higher in FK $(188.77 \pm 12.47 \mu \mathrm{g} / \mathrm{g}$. Dry Weight) than in NFK $(145.62 \pm 23.91 \mu \mathrm{g} / \mathrm{g}$. DW) extracted using deionized water. Additionally, the puerarin contents of FK were $2395.26 \pm 78.65 \mu \mathrm{g} / \mathrm{g}$. DW, compared with that of NFK $(1903.56 \pm 62.88 \mu \mathrm{g} / \mathrm{g}$. DW) extracted using deionized water. E. cristatum fermented kudzu root (Pueraria lobata) may be produced some enzyme which could be cut off glucoside bond and then 
increased the isoflavonoid contents [24]. The microbe grew and metabolized on the substrate could be produce some chemical substances contribute to the isoflavonoid and phenolic acid contents [25]. He et al. [26] recently demonstrated that FK and NFK effectively prevent $\mathrm{H}_{2} \mathrm{O}_{2}$-induced apoptosis of PC12 cell. Li et al. [27] also reported that isoflavonoid significantly prevents cells apoptosis and that estrogen may directly act on nerve growth factors and increase the number of nigral dopaminergic neurons. Some studies suggest that tea polyphenols act as antioxidants by scavenging free radicals and chelating metals, whereas other works suggest that ployphenols act as pro-oxidants, increasing the levels of intracellular ROS and contributing to mitochondria-mediated apoptosis [28].
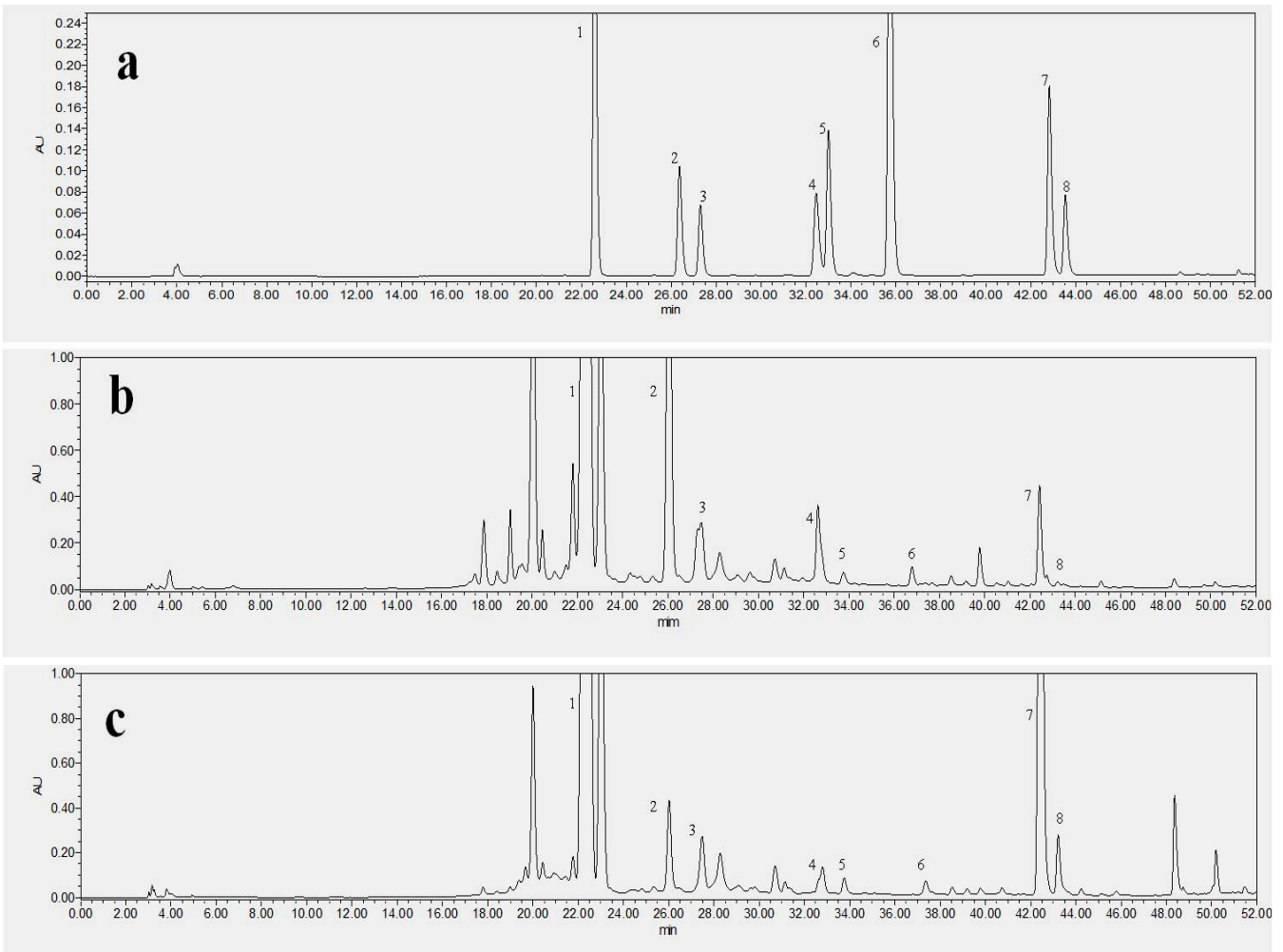

Figure 1. Reversed-phase high performance liquid chromatography (RP-HPLC) chromatogram analyzed the isoflavones of seven standard, non-fermented kudzu root (NFK), fermented kudzu root (FK). (a) including (1) Puerarin; (2) Daidzin; (3) Glycitin; (4) Genistin; (5) Ferulic acid; (6) Daidzein; (7) Glycitein; (8) Genistein; (b) NFK; (c) FK.

Table 1. Special isoflavonoid compounds of NFK and FK. The results are expressed as $\mu \mathrm{g} / \mathrm{g}$. DW.

\begin{tabular}{ccc}
\hline Special Compounds & NFK & FK \\
\hline One: Puerarin & $1903.56 \pm 62.88 \mathrm{~A}$ & $2395.26 \pm 78.65 \mathrm{~B}$ \\
Two: Daidzin & $147.13 \pm 3.39 \mathrm{~A}$ & $69.82 \pm 4.22 \mathrm{~B}$ \\
Three: Glycitin & $129.04 \pm 1.62 \mathrm{~A}$ & $91.45 \pm 9.40 \mathrm{~B}$ \\
Four: Genistin & $16.02 \pm 0.35 \mathrm{~A}$ & $11.42 \pm 0.60 \mathrm{~B}$ \\
Five: Shikimic acid & $141.18 \pm 3.82 \mathrm{~A}$ & $149.55 \pm 10.21 \mathrm{~B}$ \\
Six: Daidzein & $145.62 \pm 23.91 \mathrm{~A}$ & $188.77 \pm 12.47 \mathrm{~B}$ \\
Seven: Glycitein & $43.87 \pm 1.79 \mathrm{~A}$ & $46.40 \pm 2.80 \mathrm{~B}$ \\
Eight: Genistein & $2.16 \pm 0.25 \mathrm{~A}$ & $2.78 \pm 0.20 \mathrm{~B}$ \\
\hline
\end{tabular}

Each value represents the mean \pm S.D. $(n=3)$. Means being different capital letters $(\mathrm{A}, \mathrm{B})$ within a row under the same fermentation condition showed a significant difference $(p<0.05)$ between NFK and FK. 
2.2. Protection of PC12 Cell from $\mathrm{H}_{2} \mathrm{O}_{2}$-Induced Damage as Revealed by Cell Morphology Analysis through Phase Contrast Microscopy

The morphology of the cells was observed under an inverted microscope, the normal cells grew better than the cells damaged by $\mathrm{H}_{2} \mathrm{O}_{2}$, that is, the normal cells showed clear boundary and were apparently ellipse and full although they were dendritic (Figure 2a(a1)). When the cells were treated with $0.1 \mathrm{mM} \mathrm{H}_{2} \mathrm{O}_{2}$ for $2.5 \mathrm{~h}$, the cells shrunk and appeared round, the spacing among treated cells were significantly larger than normal cells, moreover, the cells were fragment, agminat, and necrotic (Figure 2a(a2)). The cells pre-incubated with NFK and FK for $0.5 \mathrm{~h}$ and then exposed to $\mathrm{H}_{2} \mathrm{O}_{2}$ appeared more intact than the cells of the damage group and appeared more similar to the cells of the control group (Figure $2 \mathrm{a}(\mathrm{a} 3, \mathrm{a} 4)$ ).

\section{(a)}
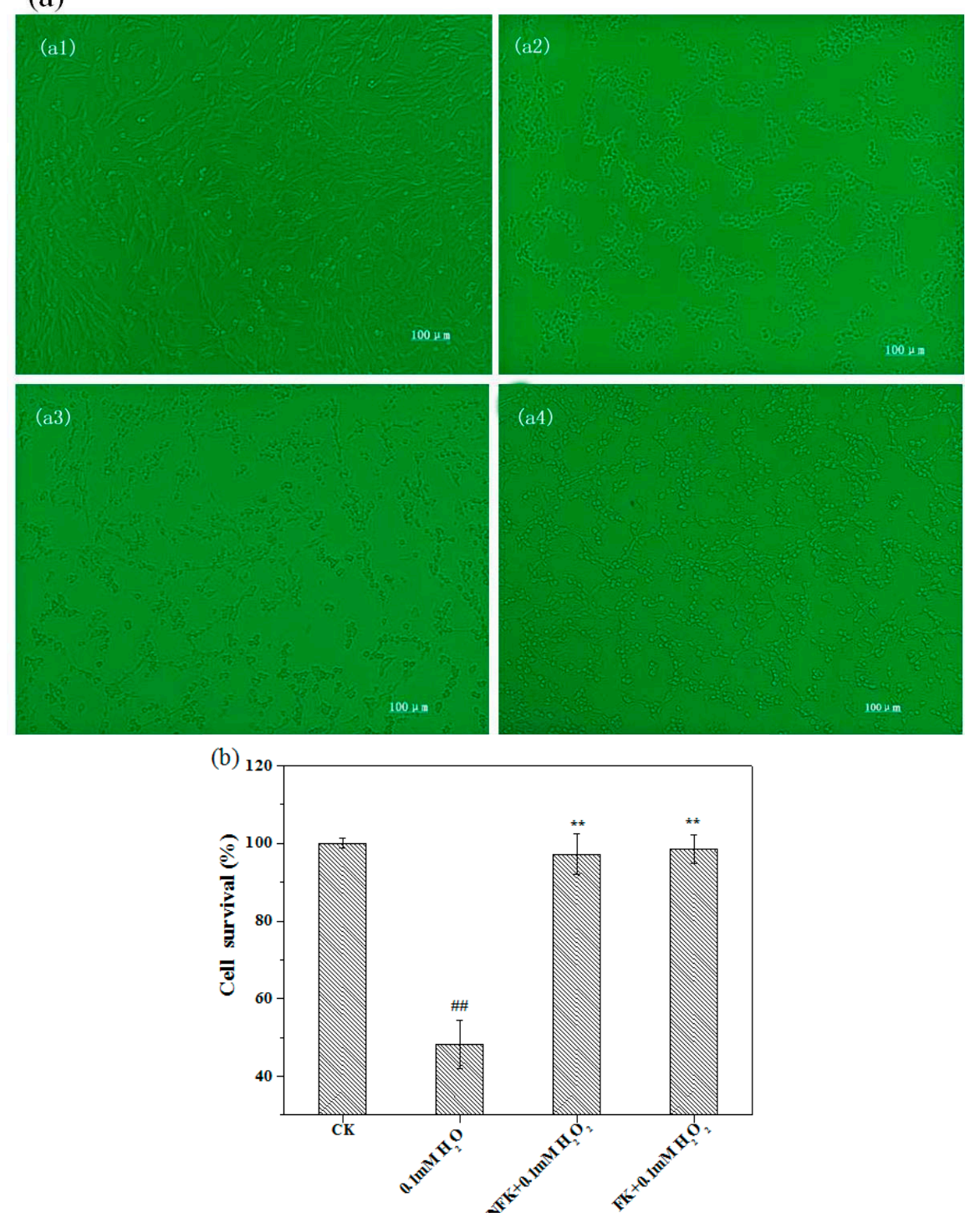

Figure 2. Effects of NFK and FK on PC12 cell damaged by $0.1 \mathrm{mM} \mathrm{H}_{2} \mathrm{O}_{2}$. (a) Cell microscope observed under an inverted microscope, (a1) CK; (a2) damage group; and (a3,a4) sample group (scale: $100 \mu \mathrm{m})$; (b) Cytotoxicity of NFK $(10 \mathrm{mg} / \mathrm{mL})$ and FK $(10 \mathrm{mg} / \mathrm{mL})$ on PC12 cells. Data are presented as mean \pm S.D. $(n=3)$. ${ }^{\# \#} p<0.01$ indicates significant differ between the control group and damage group, ${ }^{* *} p<0.01$ indicates significant difference between sample group and damage group. 
MTT assay was used to investigate the effects of NFK and FK on viability of PC12 cell damage or toxicity, the results expressed in Figure $3 \mathrm{a}$. The $\mathrm{IC}_{50}$ of the viability of PC12 cell was disrupted by $0.1 \mathrm{mM} \mathrm{H}_{2} \mathrm{O}_{2}$ within $2.5 \mathrm{~h}$ incubation as shown in Figure $3 \mathrm{~b}$, and this $\mathrm{H}_{2} \mathrm{O}_{2}$ concentration was used in the damage model. MTT was used to determine the survival rate of cells pre-incubated with FK and NFK for $0.5 \mathrm{~h}$, treated with $0.1 \mathrm{mM} \mathrm{H}_{2} \mathrm{O}_{2}$, and incubated for $2.5 \mathrm{~h}$. Figure $2 \mathrm{~b}$ showed that effectively protected the PC12 cell exerted by FK extracted using deionized water was $98.52 \pm 3.61 \%$. Based on cell survival, the protective effect of FK and NFK could be against $\mathrm{H}_{2} \mathrm{O}_{2}$-induced damage.

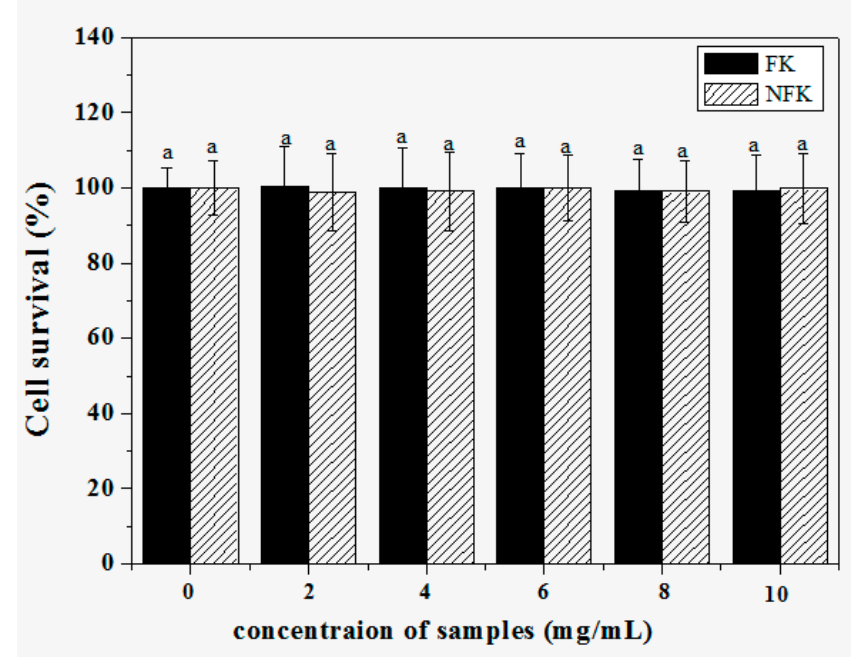

(a)

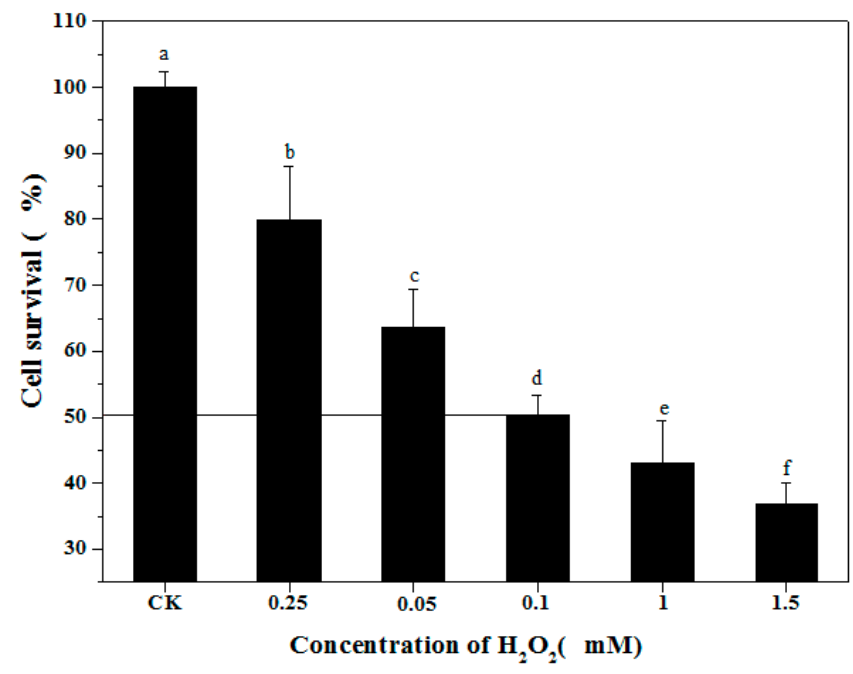

(b)

Figure 3. (a) The different concentration of NFK and FK on PC12 cells viability. Each value is expressed as the mean $\pm \mathrm{SD}(n=3)$. In a column, the same superscript letters indicates that the difference between NFK and FK is not significant $(p>0.05)$; (b) The oxidant model was evaluated by different concentration of $\mathrm{H}_{2} \mathrm{O}_{2}$ on $\mathrm{PC} 12$ cells, which treated for $0.5 \mathrm{~h}$ exposed $\mathrm{H}_{2} \mathrm{O}_{2}$. Each value is expressed as the mean $\pm \mathrm{SD}(n=3)$. Within a column, values with the different superscript letters are significantly different from each other at $p<0.05$, line indicated the $\mathrm{IC}_{50}$ value.

\subsection{LDH, CAT, and SOD Activities, GSH Content, and ROS Levels of PC12 Cell}

LDH (Lactate dehydrogenase) is a biological macromolecule that cannot be released from a normal cell unless cell membrane is damaged by an extracellular substance. To investigate the protective effect NFK and FK on cells, the LDH release was detected and the level of cells damage 
caused by $0.1 \mathrm{mM} \mathrm{H} \mathrm{H}_{2} \mathrm{O}_{2}$ in pre-incubated samples was determined. Table 2 showed that the $\mathrm{LDH}$ release $(566.45 \pm 79.43 \mathrm{U} / \mathrm{L})$ in PC12 cell in the damage group treated with $0.1 \mathrm{mM} \mathrm{H}_{2} \mathrm{O}_{2}$ for $2.5 \mathrm{~h}$ significantly $(p<0.01)$ increased compared with that in the control group. After being pre-protected for $0.5 \mathrm{~h}$ with NFK and FK extracted using deionized water, the LDH release was $468.45 \pm 19.20$ and $443.80 \pm 33.26 \mathrm{U} / \mathrm{L}$ of the cells, respectively, it were significantly $(p<0.01)$ decreased compared with that in the damage group. After treatment with NFK and FK, the viability of PC12 cell was significantly reversed as indicated by a remarkable improvement in MTT (3-(4,5-Dimethylthiazol-2-yl)-2,5-diphenyltetrazolium bromide) value and a reduced LDH release, indicating that the samples could prevent cell damage and injury after $\mathrm{H}_{2} \mathrm{O}_{2}$ treatment in PC12 cell model [29].

Table 2. Effect of NFK and FK on LDH contents, CAT and SOD activities, and GSH contents in PC12 cells.

\begin{tabular}{ccccc}
\hline LDH, CAT, SOD Activities, & \multirow{2}{*}{ Control Group } & Damage Group & \multicolumn{2}{c}{ Sample Group } \\
\cline { 3 - 4 } GSH Content & & & NFK & FK \\
\hline LDH (U/L) & $292.05 \pm 53.42$ & $566.45 \pm 79.43^{\# \#}$ & $468.45 \pm 19.20 \mathrm{a}^{* *}$ & $443.80 \pm 33.26 \mathrm{~b}^{* *}$ \\
CAT (U/mg pro.) & $9.25 \pm 1.48$ & $1.61 \pm 0.30^{\# \#}$ & $2.67 \pm 0.27 \mathrm{a}^{* *}$ & $3.63 \pm 0.61 \mathrm{~b}^{* *}$ \\
SOD (U/mg pro.) & $116.26 \pm 5.82$ & $21.07 \pm 2.81^{\# \#}$ & $27.88 \pm 1.716 \mathrm{a}^{* *}$ & $29.98 \pm 4.87 \mathrm{a} \mathrm{a}^{* *}$ \\
GSH (mmol/mg pro.) & $29.13 \pm 5.31$ & $6.17 \pm 0.39^{\# \#}$ & $14.28 \pm 0.54 \mathrm{a}^{* *}$ & $18.99 \pm 0.75 \mathrm{~b}^{* *}$ \\
\hline
\end{tabular}

Each value represents mean \pm S.D. $(n=3)$. Means being different small letters $(a, b)$ indicate a significant difference $(p<0.05)$ between the same concentrations of NFK and FK. ${ }^{\# \#} p<0.01$ indicates significant difference between the control group and the damage group, ${ }^{* *} p<0.01$ indicates significant difference between sample group and damage group, pro. represents protein.

Toxicity caused by $\mathrm{H}_{2} \mathrm{O}_{2}$ is normally accompanied by increased intracellular oxidative stress. Therefore, the effects of NFK and FK on antioxidant were analyzed by determining the different antioxidant systems in PC12 cell (Table 2). SOD being a natural superoxide free radical scavenging factor in the organism, is generally regarded as the main line of defense against tissue and cellular damage caused by cytotoxic reactive oxygen species [30,31]. SOD indirectly indicates the level of intracellular radicals. CAT is an enzyme that can decompose hydrogen peroxide into oxygen and water, wherein the hydrogen acts as metabolite during metabolic processes, moreover, CAT is the important antioxidant enzyme that decomposes hydrogen to reduce damage in cells [32]. GSH is an abundant natural neuronal antioxidant that plays a critical role in cell survival against oxidative stress. Intracellular ROS level induced by $\mathrm{H}_{2} \mathrm{O}_{2}$ in PC12 cells was examined by using the special fluorescent dye DCFH-DA, which enhances fluorescent intensity following generation of reactive intracellular metabolites [33,34].

Table 2 and Figure 4 showed that $0.1 \mathrm{mM} \mathrm{H}_{2} \mathrm{O}_{2}$ significantly reduced the levels of the anti-oxidant defense enzymes CAT and SOD, and GSH content, whereas ROS level increased in $\mathrm{H}_{2} \mathrm{O}_{2}$ treated PC12 cell. By contrast, NFK and FK increased the levels and enhanced the activities of CAT and SOD, and GSH content, whereas they reduced the ROS level in pre-treated PC12 cell. The pretreatment could prevent the oxidative damage caused by $\mathrm{H}_{2} \mathrm{O}_{2}$ toxicity with a potency of the protective effect displayed by FK (extracted using de-ionized water), which significantly $(p<0.01)$ increased CAT to $3.63 \pm 0.61 \mathrm{U} / \mathrm{mg}$ pro. min, increased SOD to $29.98 \pm 4.87 \mathrm{U} / \mathrm{mg}$ pro., and increased GSH content to $18.99 \pm 0.75 \mu \mathrm{mol} / \mathrm{mg}$ pro. The ROS levels (Figure 4 ) of NFK and FK were $334.10 \pm 14.53 \%$ and $312.97 \pm 31.86 \%$, respectively, which are significantly $(p<0.01)$ lower than the ROS level in the damage group. In PC12 cells, $\mathrm{H}_{2} \mathrm{O}_{2}$ induces overproduction of intracellular ROS and inhibition of ROS formation is protective against $\mathrm{H}_{2} \mathrm{O}_{2}$ cytotoxicity [35,36]. Flavonoid cloud decreased $\mathrm{H}_{2} \mathrm{O}_{2}$-induced ROS production and protected PC12 cells from cytotoxicity. 


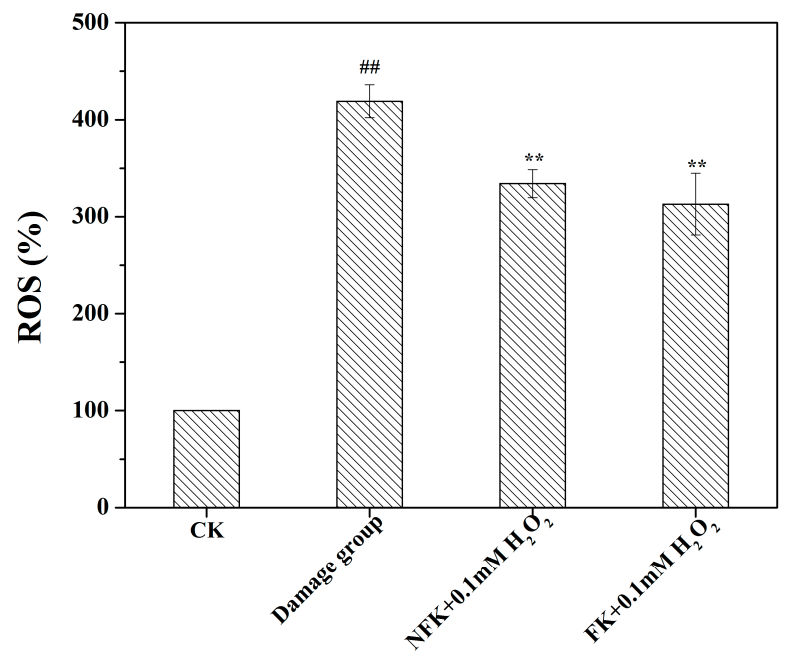

Figure 4. Intracellular ROS level of NFK $(10 \mathrm{mg} / \mathrm{mL})$ and FK $(10 \mathrm{mg} / \mathrm{mL})$ in PC 12 cells. The fluorescent probe DCFH-DA was used to the cell ROS level. Data are presented as mean \pm S.D., $(n=3)$. ${ }^{\# \#} p<0.01$ compared with the control cells; ${ }^{* *} p<0.01$ compared with the damage group.

\subsection{NFK and FK against Apoptosis of PC12 Cell as Revealed by Flow Cytometer Analysis}

Based on the possible promotion effect of NFK and FK on proliferation of $\mathrm{H}_{2} \mathrm{O}_{2}$ damaged PC12 cell, NFK and FK possibly play some protective roles to these cells $[37,38]$. Apoptosis of PC12 cell induced by $0.1 \mathrm{mM} \mathrm{H}_{2} \mathrm{O}_{2}$ was investigated through flow cytometry. Compared with that of the untreated group (CK group), the apoptotic cell of PC12 cell exposed to $0.1 \mathrm{mM}$ for $2.5 \mathrm{~h}$ significantly increased $(p<0.01)$, suggesting that the $\mathrm{PC} 12$ cell were damaged upon exposure to $\mathrm{H}_{2} \mathrm{O}_{2}$, and the apoptosis rate was $46.03 \pm 2.41 \%$ (Figure 5). However, when the cells were pre-incubated with NFK and FK prior to exposure to $0.1 \mathrm{mM} \mathrm{H}_{2} \mathrm{O}_{2}$, the observed apoptosis rate was significantly attenuated (Figures 5 and 6). When cells were pre-incubated for $0.5 \mathrm{~h}$ with NFK and FK extracted using deionized water before exposure to $0.1 \mathrm{mM} \mathrm{H}_{2} \mathrm{O}_{2}$, the cell viability was enhanced to $37.21 \pm 1.05 \%$ and $34.54 \pm 1.22 \%$, respectively. Furthermore, we determined the cytotoxic effect of NFK and FK on PC12 cell, and the results revealed that NFK and FK effectively protected the PC12 cells against damage induced by $0.1 \mathrm{mM} \mathrm{H}_{2} \mathrm{O}_{2}$.

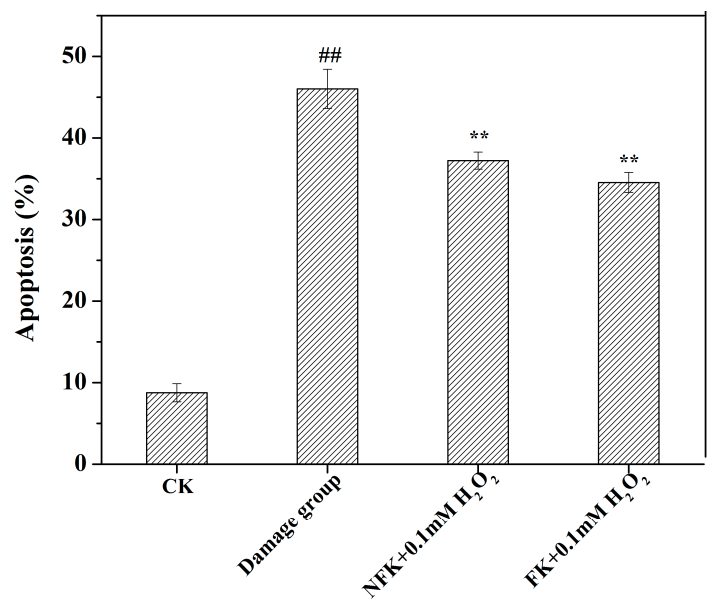

Figure 5. NFK $(10 \mathrm{mg} / \mathrm{mL})$ and FK $(10 \mathrm{mg} / \mathrm{mL})$ prevent $\mathrm{H}_{2} \mathrm{O}_{2}$-induced $\mathrm{PC} 12$ cell apoptosis. The probe Annexin V-FITC/PI was used to determine the cell apoptosis. Data are presented as mean \pm S.D., $(n=3) .{ }^{\# \#} p<0.01$ compared with the control cells; ${ }^{* *} p<0.01$ compared with the damage group. 

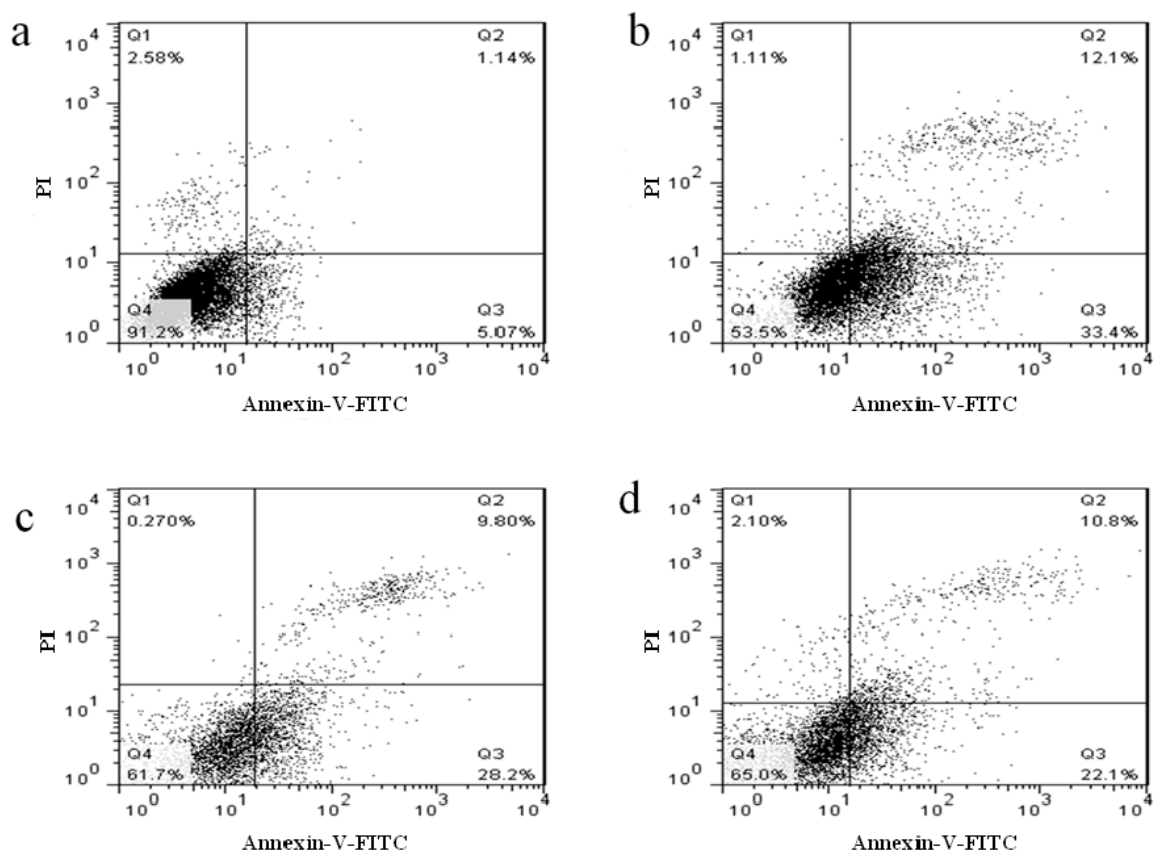

Figure 6. Cell apoptosis was measured by labeling the cells with Annexin-V-FITC and counterstaining with PI. (a) CK; (b) damage group; and (c,d) sample group. The numbers indicate the percentage of cells in each quadrant (lower left: FITC-/PI-, intact cells; lower right: FITC+/PI-, apoptotic cells; upper left: FITC-/PI+, necrotic cells; and upper right: FITC+/PI+, late apoptotic cells).

\subsection{Cell Cycle Analysis via Flow Cytometry}

To analyze the effect of NFK and FK on PC12 cell, we determined the cell cycle distribution via flow cytometry which is evaluated using PI marking in the presence of samples extracted using de-ionized water extracted. Figures 7 and 8 showed that the G1 phase of PC12 cell significantly decreased and the $\mathrm{S}$ phase significantly increased compared with those of the $0.1 \mathrm{mM} \mathrm{H}_{2} \mathrm{O}_{2}$ damage group. The PC12 cell were pretreated with NFK and FK for $0.5 \mathrm{~h}$ and then treated with $0.1 \mathrm{mM} \mathrm{H}_{2} \mathrm{O}_{2}$ for $2.5 \mathrm{~h}$, the G1 phase significantly increased, whereas the $\mathrm{S}$ phase significantly decreased compared with those in the damage group. These results demonstrated that the NFK and FK could protect the PC12 cell against damage caused by $0.1 \mathrm{mM} \mathrm{H}_{2} \mathrm{O}_{2}$.

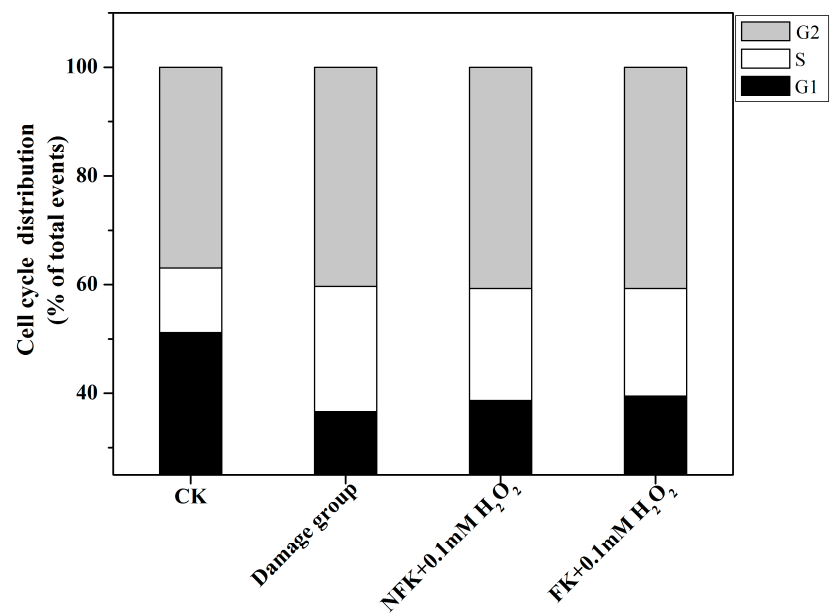

Figure 7. Effects of NFK $(10 \mathrm{mg} / \mathrm{mL})$ and FK $(10 \mathrm{mg} / \mathrm{mL})$ on $\mathrm{H}_{2} \mathrm{O}_{2}$ induced PC12 cell cycle as determined through flow cytometry. 

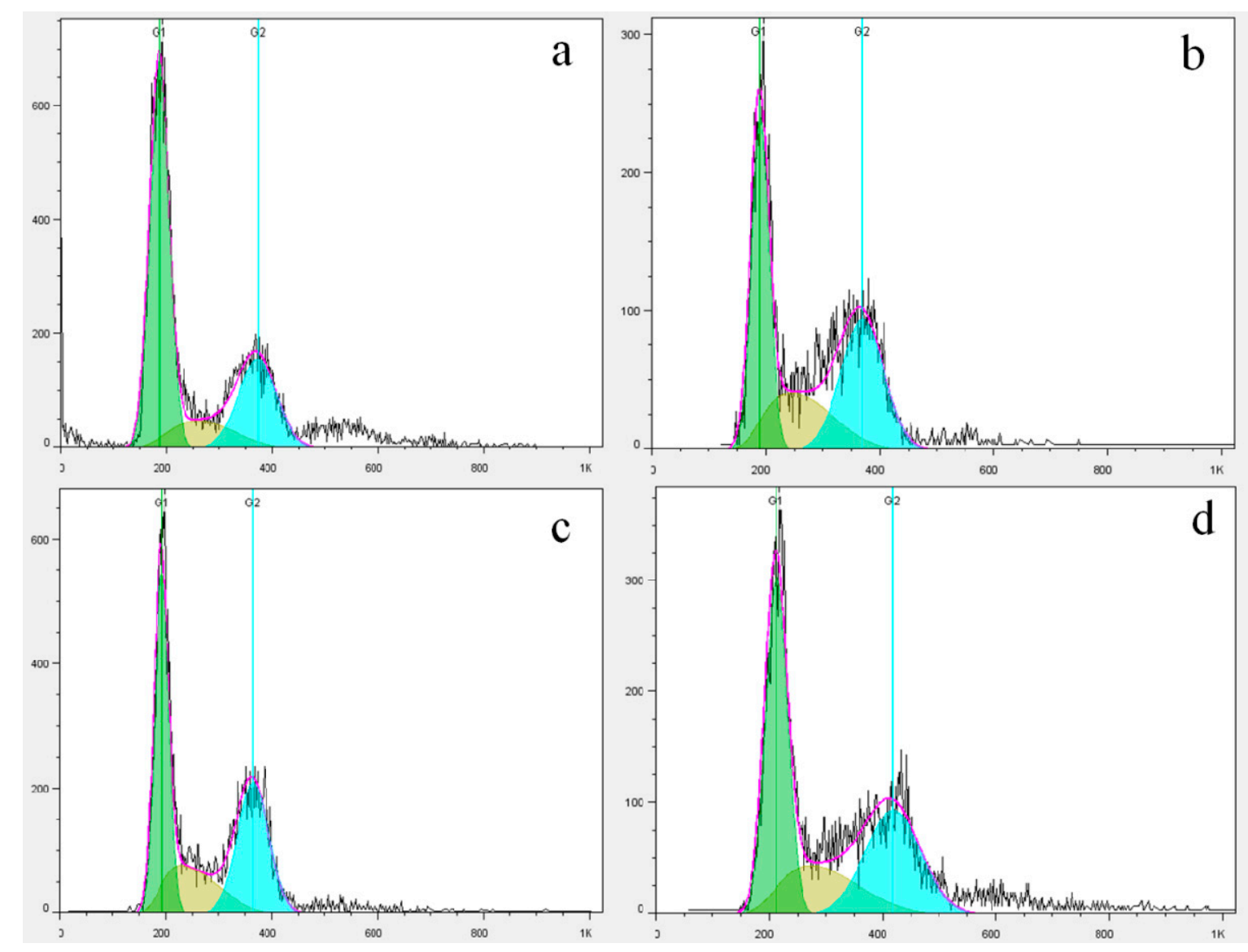

Figure 8. Cell cycle distribution of PC12 in (a) CK; (b) damage group and (c,d) sample group were analyzed through flow cytometry ( $\square$ G1, $\square$ G2, $\square$ S).

\subsection{Determination of Intracellular Caspase-3 Activity}

Caspase- 3 is a protease that is usually activated in response to cell death, and it catalyzes the breakdown of several vital cellular proteins [7]. To determine the pathway through which the NFK and FK could effectively protect the apoptosis of PC12 cell, we used a colorimetric detection assay kit used to determine caspase-3 activity. As shown in Figure 9, caspase-3 activity in CK of PC12 cell has lower significance compared with damage group. However, the $0.1 \mathrm{mM} \mathrm{H}_{2} \mathrm{O}_{2}$ induced caspase-3 activity was obviously attenuated in the sample group. Moreover, the NFK and FK extracted using deionized water could reduce caspase- 3 activity by $140.75 \pm 5.64 \%$ and $115.93 \pm 6.92 \%$ of control respectively. By contrast, NFK reduced the caspase-3 activity at a lower extent compared with the FK. These results indicated that NFK and FK treatments could effectively block the damage induced by $0.1 \mathrm{mM} \mathrm{H}_{2} \mathrm{O}_{2}$ by increasing caspase- 3 activity in PC12 cell. Inhibition of caspase- 3 activation decreases the apoptosis of neurons. In the neuroprotection of pramipexole, caspase- 3 activation induced by $\mathrm{H}_{2} \mathrm{O}_{2}$ is alleviated [39]. In the present work FK and NFK extracted by water inhibited caspase-3 activation induced by $\mathrm{H}_{2} \mathrm{O}_{2}$ which was involved in the protection for PC12 cells. 


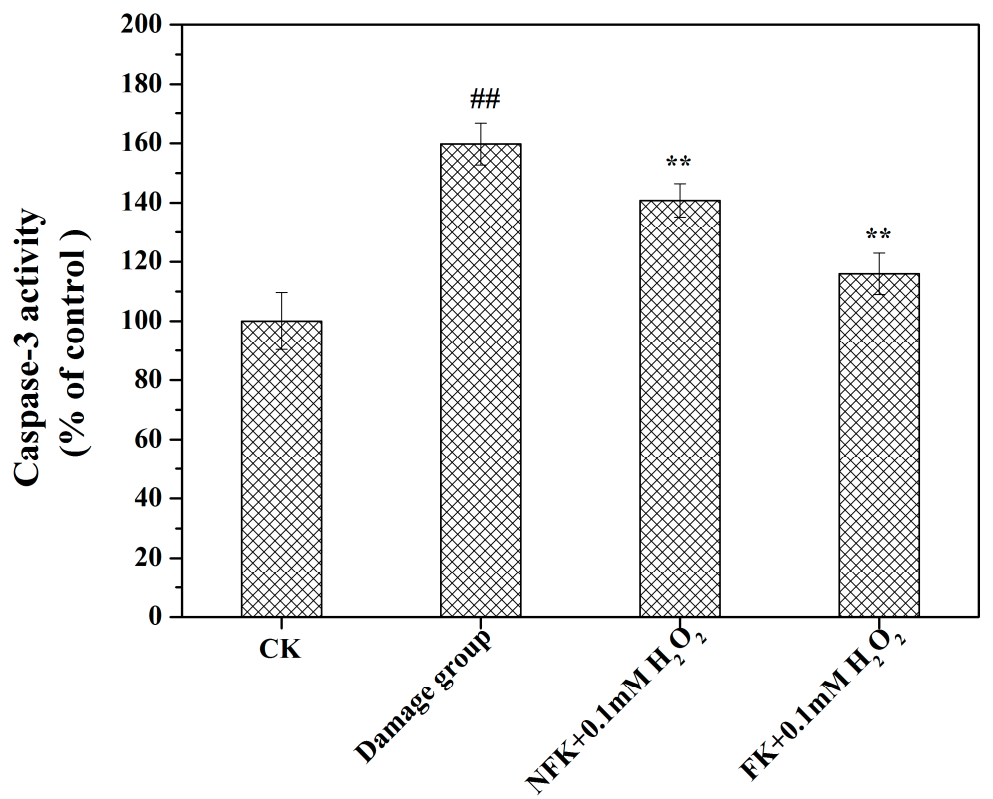

Figure 9. Effects of caspase-3 activity of NFK (10 mg/mL) and FK (10 mg/mL) on $\mathrm{H}_{2} \mathrm{O}_{2}$-treated PC12 cells. Data are presented as mean \pm S.D., $(n=3) .{ }^{\# \#} p<0.01$ compared with the control cells; ${ }^{* *} p<0.01$ compared with the $\mathrm{H}_{2} \mathrm{O}_{2}$ damage group.

The present study results similar report by the Baohua et al. [16], that the D- $\beta$-hydroxybutyrate inhibited the apoptosis of $\mathrm{PC} 12$ cells induced by $\mathrm{H}_{2} \mathrm{O}_{2}$ via inhibiting oxidative stress. $\mathrm{H}_{2} \mathrm{O}_{2}$ can cause a series of oxidative stress through cells to induce the release of cytochrome $\mathrm{C}$ from the mitochondria, thus inducing cell apoptosis. Therefore, by measuring a series of antioxidant enzyme activities and antioxidant contents in PC12 cells, we can reflect the damage of $\mathrm{PC} 12$ cells induced by $\mathrm{H}_{2} \mathrm{O}_{2}$ and the protective effect of samples on cells. Apoptosis is a more complex process, which causes many causes and ways of cell apoptosis. The flow cytometry showed that flavonoid rich extract of FK and NFK could significantly reduce the apoptosis rate of $\mathrm{PC} 12$ cells $\mathrm{H}_{2} \mathrm{O}_{2}$ damage, further studies showed that FK and NFK can alleviate $\mathrm{H}_{2} \mathrm{O}_{2}$ caused $\mathrm{S}$ phase arrest phenomenon, reduce the activity and the key enzyme Caspase-3 in the apoptotic process to achieve.

\section{Materials and Methods}

\subsection{Materials and Reagents}

Dulbecco's modified Eagle's medium (DMEM) and fetal bovine serum (FBS) were purchased from Gibco BRL (Grand Island, NY, USA). $\mathrm{H}_{2} \mathrm{O}_{2}$, 3-(4,5-dimethylthiazol-2-yl)-2,5-diphenyltetrazolium bromide (MTT), and dimethyl sulfoxide (DMSO) were purchased from Shoude Biological Co., Ltd. (Nanjing, China). Puerarin, daidzin, glycitin, daidzein, glycitein, genistein and shikimic acid were purchased from Sigma-Aldrich Chemical Co. (St. Louis, MO, USA). Annexin V-FITC/PI apoptosis detection kit was purchased from rom Beyotime Institute of Biotechnology (Beijing, China). 2,7-Dichlorofluorescein dictate (DCFH-DA) ROS kits were purchased from Sigma-Aldrich. Lactate dehydrogenase (LDH), superoxide dismutase (SOD), catalase (CAT) and reduced glutathione (GSH) assay kits were procured from Nanjing Jiancheng Bioengineering Institute (Jiangsu, China). All other chemicals and reagents were of analytical grade. Rat pheochromocytoma line 12 (PC12) cell was purchased from the Institute of Biochemistry and Cell Biology (Shanghai, China).

\subsection{Preparation of NFK and FK Extraction}

Kudzu root (Pueraria lobata) was purchased from a medical supply company in Jiangsu, China. The samples were authenticated by reliable traditional Chinese herb experts. The fungus used to ferment 
the kudzu root (Pueraria lobata) was extracted from Fu brick dark tea in the laboratory. The kudzu root (Pueraria lobata) was sterilized in an SX-300 Autoclave (TOMY Seiko Co., Ltd., Tokyo, Japan) at $121^{\circ} \mathrm{C}$ for $15 \mathrm{~min}$. After cooling to room temperature, $100 \mathrm{~g}$ of the autoclaved kudzu root (Pueraria lobata) was inoculated with $3 \mathrm{~mL}$ of E. cristatum spore suspension and then incubated at $28^{\circ} \mathrm{C}$ for 10 days (FK was fermented by E. cristatum). After fermentation, all samples were lyophilized and ground using an electric grinder (SF 180, Zhouxiang Phamaceutical Machinery Co., Ltd., Shanghai, China). Flour was passed through a $0.2 \mathrm{~mm}$ sieve and then stored in the dark at $-20{ }^{\circ} \mathrm{C}$ for further analysis.

The NFK and FK were extracted using deionized water, the sample extracts were evaporated under a reduced pressure of $40{ }^{\circ} \mathrm{C}$ and then freeze drying. The sample weighing a certain quality was re-dissolved in deionized water, and the concentration of the extracts was $10 \mathrm{mg} / \mathrm{mL}$ and this concentration was used to the cell protective assay. The above samples were filtered using sterilized $0.2 \mu \mathrm{m}$ filter membrane before being used in cell assay. The samples were analyzed by RP-HPLC using a Waters 2695 system (Aglient Technologies, Wilmington, DE, USA) with A-AORBAX SB-C 18 reverse-phase column, $4.6 \times 200 \mathrm{~mm}, 5 \mu \mathrm{m}$ particle size (Eclipse plus, Aglient, Technologies). The analysis empower software was used for controlling the instruments, for data acquisition and processing. The mobile phase consisted of deionized water as solvent A (contain $0.1 \%$ trifluoroacetic acid) and acetonitrile as solvent $B$ and the solvent flow rate was $0.7 \mathrm{~mL} / \mathrm{min}$. The elution system was: $0(95 \% \mathrm{~B}), 15 \mathrm{~min}(85 \% \mathrm{~B}), 32 \mathrm{~min}(75 \% \mathrm{~B})$ and $45 \mathrm{~min}(50 \% \mathrm{~B})$. An auto injector was used to inject $10 \mu \mathrm{L}$ of the test solution into the RP-HPLC system. The wavelength used to monitor was set at $254 \mathrm{~nm}$. The results were calculated by different standard curves and expressed as $\mu \mathrm{g} / \mathrm{g}$ of dry weight sample.

\subsection{Cell Culture and Treatment}

PC12 cell were maintained in DMEM supplemented with 10\% FBS, $100 \mathrm{U} / \mathrm{mL}$ penicillin, and $100 \mu \mathrm{g} / \mathrm{mL}$ streptomycin according to the method described by Pavlica et al. [38]. In all experiments, PC12 cell were seeded in 96-well $\left(1.5 \times 10^{5}\right.$ cells/well $)$ culture plates or 6-well culture plates $\left(2.5 \times 10^{5}\right.$ cells/well $)$ and then incubated at $37{ }^{\circ} \mathrm{C}$ in a humidified incubator containing $5 \% \mathrm{CO}_{2}$ and $95 \%$ air for $24 \mathrm{~h}$. The cells were pre-incubated for $0.5 \mathrm{~h}$ with NFK and FK extracted using deionized water, $\mathrm{H}_{2} \mathrm{O}_{2}(0.1 \mathrm{mM})$ was subsequently added into the medium and allowed to stand for $2.5 \mathrm{~h}$.

\subsection{Cell Survival Assay and LDH Activity}

Cell viability was determined using MTT colorimetric assay as described by Fang et al. (2016) [40]. After treatment, the medium was removed, and the cells were incubated with $100 \mu \mathrm{L}$ of $0.5 \mathrm{mg} / \mathrm{mL}$ MTT solution for $4 \mathrm{~h}$ at $37^{\circ} \mathrm{C}$. The medium was carefully removed, and dark blue formazan was dissolved with $150 \mu \mathrm{L}$ of DMSO for $10 \mathrm{~min}$ at room temperature. Absorbance was measured at $570 \mathrm{~nm}$ by using a micro-plate reader. Cell viability was expressed as a percentage of control group, the cell viability of which was set as $100 \%$. Cells were observed under an inverted microscope (ECLIPSE TE2000-S, Nikon, Tokyo, Japan).

Plasma membrane damage in PC12 cell was determined by the release of LDH into the medium [41]. After exposure of PC12 cell to $\mathrm{H}_{2} \mathrm{O}_{2}(0.1 \mathrm{mM})$ in the presence or absence of NFK and FK treatment for $2.5 \mathrm{~h}$, the medium was collected to determine the LDH activity by using a commercially available assay kit according to the manufacturer's protocol. The absorbance of the sample was measured at $450 \mathrm{~nm}$. The LDH activity was expressed as $\mathrm{U}$ (reaction with the medium for $15 \mathrm{~min}$ at $37^{\circ} \mathrm{C}$ producing $1 \mu \mathrm{M}$ pyruvic acid) per liter.

\subsection{Determination of SOD, GSH, CAT and ROS Levels}

Following treatment of cells with NFK and FK, the medium was removed and the cells were washed twice with PBS. Cells were collected, centrifuged, re-suspended in PBS $(0.5 \mathrm{~mL})$, dissociated by cell lysis buffer, and centrifuged for $15 \mathrm{~min}$ (12,000 rpm, $15 \mathrm{~min})$. The supernatant was used to measure the CAT and SOD activities 34 (Pavlica et al., 2010) and intracellular GSH contents by using an assay kit according to the manufacturer's instruction [42]. SOD activity was expressed as $\mathrm{U} / \mathrm{mg}$ protein, 
CAT activity was expressed as $\mathrm{U} / \mathrm{mL}$, and GSH content was expressed as $\mu \mathrm{M} / \mathrm{mg}$ pro. Intracellular proteins were detected using the BCA methods and expressed as $\mathrm{mg} / \mathrm{mL}$.

Intracellular ROS production [29] was measured using the fluorescent probe DCFH-DA, which can cross cell membrane and can be subsequently hydrolyzed by intracellular esterase to non-fluorescent DCFH [43]. After NFK and FK treatment, cells on the 6-well plates were incubated with $10 \mu \mathrm{M}$ DCFH-DA in DMEM and cultured for $0.5 \mathrm{~h}$. The cells were harvested and then suspended in PBS. Fluorescence intensity was measured by a FACSCalibur (Becton, Dickinson and Company, Franklin Lakes, NJ, USA) flow cytometer at an excitation and emission wavelengths of 488 and $525 \mathrm{~nm}$, respectively. Intracellular ROS was expressed as percentage of control.

\subsection{Flow Cytometry Analysis of Apoptosis}

Flow cytometry analysis was performed to identify and quantify the apoptotic cells by using an Annexin V-FITC/PI apoptosis detection kit. In brief, cells were treated with NFK and FK, harvested, washed twice with ice-cold PBS, re-suspended in binding buffer, and mixed with Annexin V-FITC and propidium iodide (PI). The cells were incubated in the dark for $0.5 \mathrm{~h}$ at room temperature [36], and then analyzed via flow cytometry (Becton, Dickinson and Company, Franklin Lakes, NJ, USA). Cell apoptosis was expressed as a percentage of control.

\subsection{Cell Cycle Analysis}

To elucidate the nuclear changes occurring during apoptosis, we harvested the NFK and FK treated cells were harvested through centrifugation and washed them twice with ice-cold PBS before fixation in $70 \%$ ethanol for $2 \mathrm{~h}$ or for more than $12 \mathrm{~h}$ at $4{ }^{\circ} \mathrm{C}$. The cells were subsequently washed twice with PBS, and re-suspended in $50 \mu \mathrm{g} / \mathrm{mL}$ RNase at $37^{\circ} \mathrm{C}$ for $0.5 \mathrm{~h}$, and incubated with $25 \mu \mathrm{g} / \mathrm{mL}$ PI for $0.5 \mathrm{~h}$ at $4{ }^{\circ} \mathrm{C}$ in the dark. The cells were analyzed using a flow cytometer (Becton, Dickinson and Company, Franklin Lakes, NJ, USA), and all histograms were analyzed by Flowjo software, San Carlos, CA, USA.

\subsection{Intracellular Caspaes-3 Activity Assay}

Intracellular caspase-3 activity was determined using a caspase-3 activity detection assay kit. The PC12 cells were treated with NFK and FK, after cell lysis and centrifugation at 12,000 rpm for $15 \mathrm{~min}$ at $4{ }^{\circ} \mathrm{C}$, the supernatant from lysed cells was added into the reaction mixture containing dithiothreitol and caspase-3 substrate ( $N$-acetyl-Asp-Glu-Val-Asp $p$-nitroanilide) and then further incubated for $1 \mathrm{~h}$ at $37^{\circ} \mathrm{C}$. The absorbance of the chromophore $p$-nitroanilide was detected by a microplate reader at $405 \mathrm{~nm}$ [44]. Intracellular protein content was measured by using the Broadford method and expressed as $\mathrm{mg} / \mathrm{mL}$. PC12 cells were cultured as control group, and data were expressed as a percentage of control.

\subsection{Statistical Analysis}

Data were expressed as mean \pm S.D. from at least three independent experiments. Student's $t$-test was used to compare the means between control and damage group and between the sample group and damage group. Statistical analyses were performed using one-way ANOVA. $p$-Values of $<0.05$ indicated statistical significance.

\section{Conclusions}

Isoflavonoid compounds are the active compounds in kudzu root, and their amounts were increased by E. cristatum HC-18 fermentation, for example, the daidzein increased about 1.3 times, and there are reports reporting that microbe can increase the daidzein contents [45]. The NFK and FK were used to effectively protect $\mathrm{PC} 12$ cell by $\mathrm{H}_{2} \mathrm{O}_{2}$-induced damage. The results indicate that the NFK and FK extracted using de-ionized water, and they protected the cell membrane, increased the intracellular antioxidase system load, and inhibited $\mathrm{H}_{2} \mathrm{O}_{2}$-induced apoptosis by scavenging ROS, 
and regulating the cell cycle. Moreover, this study demonstrated that the fermented kudzu can be developed to prevent and cure oxidation-related diseases, and that it presents potential applications in medical health care.

Acknowledgments: This work was co-financed by the National Natural Science Foundation of China (Nos. 31371807; 31201422). This research was supported by Jiangsu Collaborative Innovation Center of meat Production and Processing Quality and safety Control.

Author Contributions: Bo Zhang conceived and designed the experiments, performed the experiments, wrote the paper, prepared figures and/or tables, reviewed drafts of the paper. Wen Li performed the experiments. Mingsheng Dong conceived and designed the experiments, reviewed drafts of the paper.

Conflicts of Interest: The authors have no conflict of interest to declare.

\section{References}

1. Li, F.; Zhang, X.; Zheng, S.; Lu, K.; Zhao, G.; Ming, J. The composition, antioxidant and antiproliferative capacities of phenolic compounds were extracted from tartary buckwheat bran [Fagopyrum tartaricum (L.) Gaerth]. J. Funct. Foods 2016, 22, 145-155. [CrossRef]

2. Dey, T.B.; Chakraborty, S.; Jain, K.K.; Sharma, A.; Kuhad, R.C. Antioxidant phenolics and their microbial production by submerged and solid state fermentation process: A review. Trends Food Sci. Technol. 2016, 53, 60-74.

3. Bebrevska, L.; Foubert, K.; Hermans, N.; Chatterjee, S.; van, M.E.; De, M.G.; Apers, S. In vivo antioxidative activity of a quantified Pueraria lobata root extract. J. Ethnopharmacol. 2010, 127, 112-117. [CrossRef] [PubMed]

4. Fernandez-Orozco, R.; Frias, J.; Zielinski, H.; Piskula, M.K.; Kozlowska, H.; Vidal-Valverde, C. Kinetic study of the antioxidant compounds and antioxidant capacity during germination of Vigna radiata cv. emmerald, Glycine max cv. jutro and Glycine max cv. merit. Food Chem. 2008, 111, 622-630. [CrossRef]

5. Siddhuraju, P.; Becker, K. The antioxidant and free radical scavenging activities of processed cowpea (Vigna unguiculata (L.) Walp.) seed extracts. Food Chem. 2007, 101, 10-19. [CrossRef]

6. Garrido, J.; Gaspar, A.; Garrido, E.M.; Miri, R.; Tavakkoli, M.; Pourali, S.; Firuzi, O. Alkyl esters of hydroxycinnamic acids with improved antioxidant activity and lipophilicity protect PC12 cells against oxidative stress. Biochimie 2012, 94, 961-967. [CrossRef] [PubMed]

7. Olatunji, O.J.; Chen, H.; Zhou, Y. Lycium chinensis Mill attenuates glutamate induced oxidative toxicity in PC12 cells by increasing antioxidant defense enzymes and down regulating $\mathrm{ROS}$ and $\mathrm{Ca}^{2+}$ generation. Neurosci. Lett. 2016, 616, 111-118. [CrossRef] [PubMed]

8. Ji, B.S.; Gao, Y. Protective effect of trihexyphenidyl on hydrogen peroxide-induced oxidative damage in PC12 cells. Neurosci. Lett. 2008, 437, 50-54. [CrossRef] [PubMed]

9. Ma, W.; Yuan, L.; Yu, H.; Ding, B.; Xi, Y.; Feng, J.; Xiao, R. Genistein as a neuroprotective antioxidant attenuates redox imbalance induced by beta-amyloid peptides $25-35$ in PC12 cells. Int. J. Dev. Neurosci. 2010, 28, 289-295. [CrossRef] [PubMed]

10. Fan, L.; Dang, X.; Shi, Z.; Zhang, C.; Wang, K. Hydroxysafflor yellow A protects PC12 cells against the apoptosis induced by oxygen and glucose deprivation. Cell. Mol. Neurobiol. 2011, 31, 1187-1194. [CrossRef] [PubMed]

11. Xing, G.; Dong, M.; Li, X.; Zou, Y.; Fan, L.; Wang, X.; Niu, Y. Neuroprotective effects of puerarin against beta-amyloid-induced neurotoxicity in PC12 cells via a PI3K-dependent signaling pathway. Brain Res. Bull. 2011, 85, 212-218. [CrossRef] [PubMed]

12. Han, X.; Zhu, S.; Wang, B.; Chen, L.; Li, R.; Yao, W.; Qu, Z. Antioxidant action of 7,8-dihydroxyflavone protects PC12 cells against 6-hydroxydopamine-induced cytotoxicity. Neurochem. Int. 2014, 64, 18-23. [CrossRef] [PubMed]

13. Hsieh, H.M.; Wu, W.M.; Hu, M.L. Genistein attenuates D-galactose-induced oxidative damage through decreased reactive oxygen species and NF-kB binding activity in neuronal PC12 cells. Life Sci. 2011, 88, 82-88. [CrossRef] [PubMed]

14. Lu, Y.H.; Su, M.Y.; Huang, H.Y.; Lin, L.; Yuan, C.G. Protective effects of the citrus flavanones to PC12 cells against cytotoxicity induced by hydrogen peroxide. Neurosci. Lett. 2010, 484, 6-11. [CrossRef] [PubMed] 
15. Chen, X.C.; Zhu, Y.G.; Zhu, L.A.; Huang, C.; Chen, Y.; Chen, L.M.; Zhao, C.H. Ginsenoside Rg1 attenuates dopamine-induced apoptosis in PC12 cells by suppressing oxidative stress. Eur. J. Pharmacol. 2003, 473, 1-7. [CrossRef]

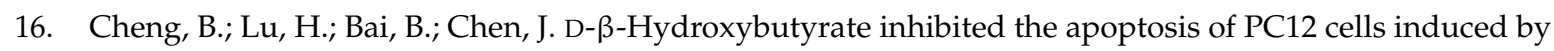
$\mathrm{H}_{2} \mathrm{O}_{2}$ via inhibiting oxidative stress. Neurochem. Int. 2013, 62, 620-625. [CrossRef] [PubMed]

17. Hwang, S.L.; Yen, G.C. Neuroprotective Effects of the Citrus Flavanones against $\mathrm{H}_{2} \mathrm{O}_{2}$-Induced Cytotoxicity in PC12 Cells. J. Agric. Food Chem. 2008, 56, 859-864. [CrossRef] [PubMed]

18. Olatunji, O.J.; Feng, Y.; Olatunji, O.O.; Tang, J.; Ouyang, Z.; Su, Z. Cordycepin protects PC12 cells against 6-hydroxydopamine induced neurotoxicity via its antioxidant properties. Biomed. Pharmacother. 2016, 81, 7-14. [CrossRef] [PubMed]

19. Lin, C.M.; Lin, R.D.; Chen, S.T.; Lin, Y.P.; Chiu, W.T.; Lin, J.W.; Lee, M.H. Neurocytoprotective effects of the bioactive constituents of Pueraria thomsonii in 6-hydroxydopamine (6-OHDA)-treated nerve growth factor (NGF)-differentiated PC12 cells. Phytochemistry 2010, 71, 2147-2156. [CrossRef] [PubMed]

20. Zhang, L.; Xing, D.; Zhu, D.; Chen, Q. Low-power laser irradiation inhibiting A $\beta_{25-35}$-induced PC12 cell apoptosis via PKC activation. Cell. Physiol. Biochem. 2008, 22, 215-222. [CrossRef] [PubMed]

21. Chen, S.B.; Liu, H.P.; Tian, R.T.; Yang, D.J.; Chen, S.L.; Xu, H.X.; Xie, P.S. High-performance thin-layer chromatographic fingerprints of isoflavonoids for distinguishing between Radix Puerariae Lobate and Radix Puerariae Thomsonii. J. Chromatogr. A 2006, 1121, 114-119. [CrossRef] [PubMed]

22. Wang, L.; Yang, B.; Du, X.; Yi, C. Optimisation of supercritical fluid extraction of flavonoids from Pueraria lobata. Food Chem. 2008, 108, 737-741. [CrossRef] [PubMed]

23. Cao, X.; Yu, T.; Zhang, T.; Xin, L.; Ito, Y. Separation and purification of isoflavones from Pueraria lobata by high-speed counter-current chromatography. J. Chromatogr. A 1999, 855, 709-713. [CrossRef]

24. Chuankhayan, P.; Rimlumduan, T.; Svasti, J.; Cairns, J.R. Hydrolysis of soybean isoflavonoid glycosides by dalbergia $\beta$-glucosidases. J. Agric. Food Chem. 2007, 55, 2407-2412. [CrossRef] [PubMed]

25. Pyo, Y.H.; Lee, T.C.; Lee, Y.C. Enrichment of bioactive isoflavones in soymilk fermented with $\beta$-glucosidase-producing lactic acid bacteria. Food Res. Int. 2005, 38, 551-559. [CrossRef]

26. He, Z.; Hu, M.; Zha, Y.H.; Li, Z.C.; Zhao, B.; Yu, L.L.; Qian, Y. Piracetam Ameliorated Oxygen and Glucose Deprivation-Induced Injury in Rat Cortical Neurons Via Inhibition of Oxidative Stress, Excitatory Amino Acids Release and P53/Bax. Cell. Mol. Neurobiol. 2014, 34, 539-547. [CrossRef] [PubMed]

27. Li, X.L.; Zhou, H.B.; Cheng, W.D.; Meng, X.H.; Zhang, Q.J.; Wang, L.X. Effect of phytoestrogen isoflavone on $\mathrm{MPP}^{+}$-induced apoptosis in PC12 cells. Biomed. Prev. Nutr. 2011, 1, 67-69. [CrossRef]

28. Crispo, J.A.; Piche, M.; Ansell, D.R.; Eibl, J.K.; Tai, I.T.; Kumar, A.; Tai, T.C. Protective effects of methyl gallate on $\mathrm{H}_{2} \mathrm{O}_{2}$-induced apoptosis in PC12 cells. Biochem. Biophys. Res. Commun. 2010, 393, 773-778. [CrossRef] [PubMed]

29. Chang, R.; Zhou, R.; Qi, X.; Wang, J.; Wu, F.; Yang, W.; Yu, J. Protective effects of aloinon oxygen and glucose deprivation-induced injury in PC12 cells. Brain Res. Bull. 2016, 121, 75-83. [CrossRef] [PubMed]

30. Xiao, X.; Liu, J.; Hu, J.; Zhu, X.; Yang, H.; Wang, C.; Zhang, Y. Protective effects of protopine on hydrogen peroxide-induced oxidative injury of PC12 cells via $\mathrm{Ca}^{2+}$ antagonism and antioxidant mechanisms. Eur. J. Pharmacol. 2008, 591, 21-27. [CrossRef] [PubMed]

31. Korenić, A.; Boltze, J.; Deten, A.; Peters, M.; Andjus, P.; Radenović, L. Astrocytic mitochondrial membrane hyperpolarization following extended oxygen and glucose deprivation. PLoS ONE 2014, 9, e90697. [CrossRef] [PubMed]

32. Li, W.; Wei, M.M.; Wu, J.J.; Rui, X.; Dong, M.S. Novel fermented chickpea milk with enhanced level of -aminobutyric acid and neuroprotective effect on PC12 cells. Peer J. 2016, 4, e2292. [CrossRef] [PubMed]

33. Shulyakova, N.; Sidorova-Darmos, E.; Fong, J.; Zhang, G.; Mills, L.R.; Eubanks, J.H. Over-expression of the Sirt3 sirtuin Protects neuronally differentiated PC12 Cells from degeneration induced by oxidative stress and trophic withdrawal. Brain Res. 2014, 1587, 40-53. [CrossRef] [PubMed]

34. Suganthy, N.; Devi, K.P. Protective effect of catechin rich extract of Rhizophora mucronata against $\beta$-amyloid-induced toxicity in PC12 cells. J. Appl. Biomed. 2016, 14, 137-146. [CrossRef]

35. Benedí, J.; Arroyo, R.; Romero, C.; Martín-Aragón, S.; Villar, A.M. Antioxidant properties and protective effects of a standardized extract of hypericum perforatum on hydrogen peroxide-induced oxidative damage in PC12 cells. Life Sci. 2004, 75, 1263-1276. [CrossRef] [PubMed] 
36. Hong, H.; Liu, G.Q. Protection against hydrogen peroxide-induced cytotoxicity in PC12 cells by scutellarin. Life Sci. 2004, 74, 2959-2973. [CrossRef] [PubMed]

37. Liu, E.; Du, X.; Ge, R.; Liang, T.; Niu, Q.; Li, Q. Comparative toxicity and apoptosis induced by diorganotins in rat pheochromocytoma (PC12) cells. Food Chem. Toxicol. 2013, 60, 302-308. [CrossRef] [PubMed]

38. Pavlica, S.; Gebhardt, R. Protective effects of flavonoids and two metabolites against oxidative stress in neuronal PC12 cells. Life Sci. 2010, 86, 79-86. [CrossRef] [PubMed]

39. Fujita, Y.; Izawa, Y.; Ali, N.; Kanematsu, Y.; Tsuchiya, K.; Hamano, S. Pramipexole protects against ho-induced pc12 cell death. Naunyn-Schmiedeberg's Arch. Pharmacol. 2006, 372, 257-266. [CrossRef] [PubMed]

40. Fang, S.Q.; Wang, Y.T.; Wei, J.X.; Shu, Y.H.; Xiao, L.; Lu, X.M. Beneficial effects of chlorogenic acid on alcohol-induced damage in PC12 cells. Biomed. Pharmacother. 2016, 79, 254-262. [CrossRef] [PubMed]

41. Wang, F.; Liu, Q.; Wang, W.; Li, X.; Zhang, J. A polysaccharide isolated from Cynomorium songaricum Rupr. protects PC12 cells against $\mathrm{H}_{2} \mathrm{O}_{2}$-induced injury. Int. J. Biol. Macromol. 2016, 87, 222-228. [CrossRef] [PubMed]

42. Eslami, H.; Sharifi, A.M.; Rahimi, H.; Rahati, M. Protective effect of telmisartan against oxidative damage induced by high glucose in neuronal PC12 cell. Neurosci. Lett. 2014, 558, 31-36. [CrossRef] [PubMed]

43. Sun, L.; Chen, W.; Meng, Y.; Yang, X.; Yuan, L.; Guo, Y. Interactions between polyphenols in thinned young apples and porcine pancreatic alpha-amylase: Inhibition, detailed kinetics and fluorescence quenching. Food Chem. 2016, 208, 51-60. [CrossRef] [PubMed]

44. Xiong, C.; Li, Q.; Chen, C.; Chen, Z.; Huang, W. Neuroprotective effect of crude polysaccharide isolated from the fruiting bodies of Morchella importuna against $\mathrm{H}_{2} \mathrm{O}_{2}$-induced PC12 cell cytotoxicity by reducing oxidative stress. Biomed. Pharmacother. 2016, 83, 569-576. [CrossRef] [PubMed]

45. Hati, S.; Vij, S.; Singh, B.P.; Mandal, S. $\beta$-Glucosidase activity and bioconversion of isoflavones during fermentation of soymilk. J. Sci. Food Agric. 2015, 95, 216-220. [CrossRef] [PubMed]

(C) 2017 by the authors. Licensee MDPI, Basel, Switzerland. This article is an open access article distributed under the terms and conditions of the Creative Commons Attribution (CC BY) license (http:/ / creativecommons.org/licenses/by/4.0/). 